\title{
SELF-REGULATORY ORGANIZATIONS IN THE FINANCIAL MARKETPLACE
}

N.Polezhaeva

A Federal Law "On Self-Regulatory Organizations in the Financial Marketplace" (hereinafter "the Federal Law on SROs in FMP) was adopted on 13 July 2015 and is due to come into force on 11 January 2016. The adopted Federal Law saw just minor amendments despite serious criticism brought in against it by the professional and academic communities in the process of its development and submission to the State Duma (the lower house of Russia's parliament) $)^{2}$ for consideration. Thus, a new system in Russia is under construction, which aims to regulate SROs in the financial marketplace, in which the Bank of Russia is actively involved, and it is the financial markets regulator that decides how actively it will be involved. However, the new system may pose some risks for the independent nature of SROs.

The generality of the Federal Law on SROs in FMP is determined not only by that it regulates 16 types of self-regulatory organizations (hereinafter "SROs") irrespective of the type of SROs financial organizations, from brokers to agricultural consumer credit co-operatives (Paragraph 1, Article 3 thereof), but also that it contains "frame" regulations of self-regulation; the specifics of regulating the relations arising from the SROs activity are set by either corporate by-laws (in-hose regulations) or banking regulations issued by the Bank of Russia in the capacity of financial markets regulator.

The Federal Law on SROs in FMP makes no distinction between too many types of activities carried out by financial market actors. However, it would appear more reasonable to adopt special acts aimed to enhance the legislative regulation of self-regulation.

As to granting and terminating the SRO status, the Federal Law on SROs in FMP establishes that the non-commercial organization may be granted the SRO status with respect to a single or various types of activity of financial organizations, provided that the SRO members account for at least $26 \%$ of the total number of financial organizations which carry out a particular type of activity (Paragraph 2, Subparagraph 1, Paragraphs 4, 5, Article 3 thereof). Hence under the Law, the number of SROs of a single type is limited to three SPOs, which may, along with the mandatory SRO membership, increase largely the risk of monopolizing the financial market.

Additionally, to be granted the SRO status, non-profit organizations must meet the requirements set forth in the Federal Law on SROs in FMP as to inter-

1 Federal Law of 13 August 2015 No. 223-FZ "On Self-Regulatory Organizations in the Financial Marketplace and Introduction of Amendments to Articles 2 and 6 of the Federal Law "On the Introduction of Amendments to Certain Legislative Acts of the Russian Federation"”" // Rossyiskaya Gazeta, 2015. No. 157.

2 Giving his comments on the Draft Bill No. 652159-6 "On Self-Regulatory Organizations in the Financial Marketplace", PARTAD (a self-regulatory organization) Chairman of the Board Lanskov P.M noted that professional players in the securities market and their self-regulatory organizations receive only what they already have, but in the form of delegating powers. See http://russianforumsro.ru/. 
nal standards, governing boards ${ }^{1}$ and special-purpose bodies ${ }^{2}$ (Paragraph 4, Article 3 thereof).

The Bank of Russia may not have representatives in the governing board of SROs (Paragraph 3, Article 20 thereof). However, the Bank of Russia has a great impact on appointing the SRO CEO. The Bank shall set the procedure for approving the CEO and may impose additional business reputation requirements for the CEO. A SRO shall apply to the Bank of Russia for approving the SRO's nominee for CEO, and it is at the discretion of the Bank of Russia to accept or reject the nominee. Additionally, the Bank of Russia may hold the SRO to substitute the SRO CEO (Subparagraph 4, Paragraph 3, Paragraphs 4, 5, Article 24 thereof).

With such a powerful mandate the Bank of Russia under certain conditions may have an adverse effect on the Council of self-regulatory organizations (or a person who represents the interests of a SRO), which aims to coordinate the SROs' interests and representation in the Bank of Russia, including by way of the Council's Chairperson attending meetings of the Bank of Russia Expert Council, submitting proposals for the agenda and making a minority report at such meetings, because the Council is comprised of SROs' CEOs, and the respective provision on the Council shall be approved by Bank of Russia's banking regulation (Article 31 thereof).

A non-profit organization shall be granted the SRO status on the date of registration with the Unified State Register of Self-regulatory Organizations operating in the financial market and shall cease to hold the SRO status from the date of removal from the register, according to a decision of the Bank of Russia which maintains the register (Paragraphs 6, 7, 12, Article 3, Article 26 thereof). The Federal Law on SROs in FMP contains an exhaustive list of grounds on which the Bank of Russia may decide not to register the nonprofit organization (Paragraph 11, Article 3 thereof), thereby helping avoid respective abuses on the side of the financial markets regulator.

Bank of Russia's decision on terminating the SRO status shall be made in accordance with the organization's application for the SRO status termination and in the case of liquidation thereof. The Bank of Russia may decide to terminate the SRO status if the organization has failed to meet the requirements set forth in the Federal Law on SROs in FMP, as well as other imposed requirements, or if the organization has repeatedly failed to meet or repeatedly (crudely) breached the requirements (Article 27 thereof). Where any breach of the foregoing requirements is detected by the Bank of Russia's oversight, the financial markets regulator may take measures, other than the SRO status termination, against the SRO, that is, the regulator may charge a penalty, hold the organization to replace its CEO, suspend all or some of the functions of the organization (Paragraphs 1-4, Article 28 thereof).

The Federal Law on SROs in FMP contains other general rules and provisions concerning the SRO activity, e.g., SROs information disclosure and

1 The general meeting of the members; the standing governing board; the executive body, if the charter of the organization allows for establishing such body; the CEO (Articles 20-24 thereof).

2 The authority in charge of monitoring the compliance of SRO members with the requirements set forth in the laws and regulations of the Russian Federation, Bank of Russia's banking regulations, SROs' standards and other by-laws, SRO membership requirements; the body in charge of considering cases on enforcement measures against SRO members (Article 25 thereof). 
protection (Article 13 thereof), considering SROs applications (Article17 thereof), restricting the rights of SROs and its employees (Article 19 thereof), cooperation between SROs and federal executive bodies (Article 32 thereof).

The Federal Law on SROs in FMP contains a no exhaustive list of sources that make up the SROs assets and limits the ceiling amount of entrance membership fee to 100,000 , thus not allowing SROs to build up entry barriers. Furthermore, the Bank of Russia may cut the fee, including with regard to a specific type of SROs (Article 18 thereof).

The Bank of Russia may authorize a SRO to receive reports from its members according to a list of reports to be set by the Bank of Russia. The Bank of Russia shall also set the procedure for delegating and exercising such authorities, including their scope and completeness, the procedure and the grounds for terminating thereof (Article 7 thereof). The Federal Draft Law on SROs in FMP previously provided for delegating the equal scope of authorities to SROs of the same type, as well as the Bank of Russia was entitled to delegate other authorities, e.g., to assess the performance of the managers and employees of SRO members. Removing the foregoing provisions from the Federal Law on SROs in FMP has made the Law less autocratic over the regulated agents, thus being more in agreement with the SROs independent nature.

The Bank of Russia and SROs may cooperate to jointly work on draft regulations issued by the Bank of Russia. While drafting Bank of Russia's financial markets regulations, which concern a SRO and its members, the Bank of Russia must at the SRO initiative submit such draft regulations for consideration to specified associations (Article 30 thereof). Although the final word rests with the Bank of Russia, the legislation of this provision constitutes some kind of conciliatory gesture toward SROs.

The Federal Law on SROs in FMP has a specific feature, that is, the SRO standards - documents which set the requirements for SRO members and regulate relationships between SROs, its members, customers - are divided into base and internal (in-house) standards (Articles 4-6 thereof).

The base standards are binding on all financial organizations carrying out a certain type of activity regardless of their SRO membership.

SROs must develop draft base standards and submit them for consideration to the Bank of Russia's Standards Committee in charge of financial organizations of a certain type of activity ${ }^{1}$ : risk management; corporate governance; internal control; protecting the rights and interests of individuals and legal entities as recipients of financial services provided by members selfregulatory organizations; performing transactions in the financial market.

The Bank of Russia shall set a list of base standards and requirements and their contents, which must be developed by SROs of a certain type, a procedure for considering and approving the standards, the grounds for not accepting a given standard.

Not more than a single base standard may be approved for a single type of activity carried out by financial organizations and a single type of the base standard. Unless otherwise decided by the Bank of Russia, standards shall continue in force when a given SRO is liquidated.

1 At least two thirds of the Standards Committee members must be represented by SROs. The provision on the Standards Committee shall be approved by the Bank of Russia. The key functions and the composition of the Standards Committee are described in detail in Paragraphs 4, 5, Article 5 thereof. 
The internal standards are binding on SRO members and, if stipulated by the internal standards, associated members (financial organizations which are members of another SRO of the same type, as well as other persons (Article 9 thereof).

SROs must develop and approve internal standards for inspecting their members, membership requirements, a system and procedure for taking enforcement measures against SRO members, business reputation requirements for the SRO executives, and business practice rules for the SRO employees.

The basic scope of work that SROs must perform is develop and set standards and rules of practice for their members. A SRO must have a free hand in terms of regulating the activity of its members within the duties imposed on it by the government. Otherwise, it should be treated as entirely different agent (e.g., a quasipublic organization), not SRO.

The Federal Law on SROs in FMP imposes no distinct limits on the involvement of the financial markets regulator in developing SRO standards. Excessive involvement of the Bank of Russia may have an adverse effect on the quality of SROs regulation, because this will neglect one of the benefits offered by self-regulation, that is, the confidence between "the regulated" and "the regulators". The United States already encountered a similar problem, when the government regulator initiated the standard-setting for NASD SROs, and exclusion of the NASD members from developing the standards resulted in poor compliance with the respective requirements. The Russian regulator should take into account this practice.

Under the Federal Law on SROs in FMP, SRO membership is binding on a financial organization if there is a SRO whose type of activity is the same as that of the financial organization.

Mandatory SRO membership under certain conditions may become a threat for financial organizations and their customers and the government, especially if licensing of the activity in the financial market remains in place. The threat may be posed by extra costs pertaining to double control, conspiracy, sale/purchase of membership, building up barriers against new companies. However, it should be noted that the mandatory membership alone is not a threat for the SRO private-law status unless it is combined with reduced number of organizations and excessive government involvement, as was demonstrated convincingly in the U.S. practice, when all brokers and dealers had to be ${ }^{1}$ SRO members of FINRA (Financial Industry Regulatory Authority), which is in large part a quasipublic company.

A financial organization may be a member of only a single SRO of a certain type. A financial organization whose activity corresponds to various types of SROs may be a member of various SROs of the same type or a single SRO holding the SRO status with regard to the respective types of activity carried out by the financial organization (Article 8 thereof). The given standard is in line with the provisions set forth in Federal Law "On Self-Regulatory Organizations" $2007^{2}$ (hereinafter "the Federal Law on SROs") (Paragraphs 3, 4, Article 5 thereof) and aims to set a single legislative standardization for the specific

1 Exchange SROs delegate some of their functions which regulate the activity of FINRA members.

2 Federal Law of 1 December 2007 No. 315-FZ "On Self-Regulatory Organizations" // Collection of Legislative Acts of the Russian Federation, 3 December 2007, No. 49, p. 6076. 
type of activity which the financial organization carries out in the financial market.

As to the admission and termination as a SRO member, the Federal Law on SROs in FMP sets the requirements for admission as a SRO member and candidate member (for persons who hold no licenses (permits), an exhaustive list of grounds for refusing admission as a SRO member or candidate member; the cases, the term and some specifics concerning the termination of membership (Articles 10, 11 thereof). SROs shall set the requirements for admission as a SRO member, which must not contradict the requirements set by the Bank of Russia (Paragraph 1, Article 10 thereof).

SROs shall make sure, including by way of planned and random inspections, that their members comply with the requirements set forth in the laws and regulations of the Russian Federation, Bank of Russia's regulations, SROs standards and other by-laws (Article14 thereof).

Note that the Federal Draft Law on SROs in FMP initially envisaged that SROs may not be authorized to monitor the compliance of their members with the laws and regulations of the Russian Federation, Bank of Russia's banking regulations unless the relevant authority is provided by the Bank of Russia (Subparagraph 1, Paragraph 1, Article 7 thereof). It appears that the removal of this provision from the adopted law is the most essential concession the lawmakers made in response to the criticism brought in against the law by the professional community.

The Federal Law on SROs in FMP contains a no exhaustive list of measures to be taken against SRO members who violate the regulations (Articles 15, 16 thereof). The procedure for considering enforcement cases against SRO members and the measures to be taken shall be set, including in accordance with the banking regulations issued by the Bank of Russia (Paragraph 2, Article 16 thereof).

Exclusion of a particular member from the SRO membership may be decided by not less than $75 \%$ of member votes of the SRO body in charge of dealing with cases on enforcement measures against SRO members. The body may decide to recommend to the SRO standing governing board to exclude a financial organization from the SRO membership. Other measures shall be decided by the majority of member votes of the body and come into force on the date when they are approved by the foregoing body (Paragraphs 4, 5, Article 16 thereof).

Given that SRO membership becomes a requirement for carrying out certain types of activity in the financial market, it appears that lawmakers seek to make sure that market entry is not blocked, through making an exhaustive list of grounds for refusing admission as a SRO member and imposing strict requirements for the exclusion procedure.

The financial markets regulator, apart from the abovementioned powers of the Bank of Russia over SROs, may set requirements for making a budget which reflects SROs ability to perform their functions and must be provided by organizations seeking the self-regulatory status (Subparagraph 6, Paragraph 7, Article 3 thereof); sets the contents of the reports to be submitted by SROs (Paragraph 9, Article 28 thereof); and is authorized to perform some other functions (Subparagraph 9, Paragraph 7, Article 3 thereof). The autonomous nature of associations of financial organizations, which is the SRO status requirement, depends on Bank of Russia's approach towards 
exercising a wide range of powers which the Federal Law on SROs in FMP delegates to the financial markets regulator.

Thus, a new system is under construction in Russia, which aims to regulate SROs in the Financial Marketplace, with active involvement of the Bank of Russia, and it is the financial markets regulator that sets the degree of such involvement.

The new system may pose some risks for SROs independency:

- developing and setting SRO standards is subject to broader legislative regulation, the Bank of Russia has broader powers in this area;

- some of the SRO natural functions are limited (SRO CEO appointment, reporting by SRO members);

- reduced number of similar-type SROs combined with the mandatory SRO membership requirement for financial organizations and retained licensing for them.

Additionally, it remains unclear what kind of role is played by the laws regulating the activity of certain types of SROs financial organizations, and the Federal Law on SROs which covers certain types of SROs falling within the scope of the Federal Law on SROs in FMP (SRO consumer credit co-operatives, micro financial organizations, etc.), because no respective amendments have been made to them to date ${ }^{1}$.

1 For example, Paragraph 1, Article 48 of Federal Law of 22 April 1996 No. 39-FZ "On the Securities Market" (see Collection of Legislative Acts of the Russian Federation, No. 17, 22 April 1996, p. 1918); Paragraph 1, Article 36.26 Federal Law of 7 May 1998 No. 75-FZ "On Nongovernment Pension Funds" (see Collection of Legislative Acts of the Russian Federation, No. 19, 11 May 1998, p. 2071); Clause 1, Article 56 of Federal Law of 30 December 2004 No. 215-FZ "On Housing Savings Co-operatives" (see Collection of Legislative Acts of the Russian Federation, 3 January 2005, No. 1 (Part 1), p. 41) contains an explicit reference to the fact that the agents whose business activity is covered by the laws join SRO associations on a voluntary basis. 